\title{
Hepatocyte Growth Factor Activator
}

National Cancer Institute

\section{Source}

National Cancer Institute. Hepatocyte Growth Factor Activator. NCI Thesaurus. Code C127008.

Hepatocyte growth factor activator ( $655 \mathrm{aa}, \sim 71 \mathrm{kDa}$ ) is encoded by the human HGFAC gene. This protein is involved in the proteolysis of single-chain hepatocyte growth factor. 